\title{
Populations of Small Mammals on an Electric Transmission Line Area in Southeastern Pennsylvania, U.S.
}

\author{
Richard H. Yahner and Richard T. Yahner
}

The Green Lane Research and Demonstration Project has had three objectives since 1987: to determine the effectiveness of mechanical and herbicidal maintenance treatments on control of undesirable trees, development of tree-resistant plant cover types, and wildlife and species of high public interest (Yahner and Hutnik 2005). The wire-border zone method of vegetation management was implemented on the electrical transmission line area (hereafter, right of way [ROW]) in 1987 (Yahner and Hutnik 2004, 2005), producing a tree-resistant forb-shrub-grass cover type in wire zones and a tall shrub cover type in border zones.

Small mammals are important wildlife species by consuming tree seeds (Bramble et al. 1992), thereby reducing invasion of undesirable tree species on a ROW (Yahner et al. 2007). Small mammals also serve as prey for a variety of predators (Merritt 1987). In a previous study conducted in 1989 through 1990 (Bramble et al. 1992) and 2004 through 2005 (Yahner et al. 2007), at least seven species of small mammals were noted on the State Game Lands (SGL) 33 ROW in Center County, Pennsylvania, U.S.; long-term studies of small mammals on a ROW are virtually nonexistent. Our objectives were to determine relative abundance and species richness (number of species) in four cover types along the ROW, resulting from herbicidal and mechanical maintenance of the vegetation, and in the adjacent forest.

\section{STUDY AREA AND METHODS}

Treatments on the ROW consisted of two units each of handcut, mowing, mowing plus herbicide, stem-foliage spray, and foliage spray. Five cover types were selected for study: adjacent forest (serving as a reference), tree sprout, shrub, shrub-forb, and grass. Major trees in forest cover type included red maple (Acer rubrum), white ash (Fraxinus americana), hickory (Carya spp.), and black cherry (Prunus serotina). Tree sprout was in the wire zone of a handcut unit; stumps were primarily white ash, and other plants included multiflora rose (Rosa multiflora), Japanese honeysuckle (Lonicera japonica), blackberry (Rubus allegheniensis), poison ivy (Toxicodendron radicans), goldenrod (Solidago spp.), and grass (Panicum spp.). Shrub was in the border zone of a mowing plus herbicide unit; principal shrubs were Japanese honeysuckle, blackberry, dewberry ( $R$. hispidus), and poison ivy. Shrub-forb was well developed in the wire zone of a stem-foliage unit; vegetation consisted principally of dewberry, Japanese honeysuckle, blackberry, goldenrod, and grass. Grass (mainly fall panic grass [Panicum spp.]) was in wire zones, with some common sow-thistle (Sonchus oleraceus) and mile-a-minute (Polygonum perfoliatum).

Mammals were surveyed monthly (May through November 2005, May through October 2006, by placing six metal live traps in a $2 \times 3$ grid in a $10 \times 15 \mathrm{~m}(33 \times 49.5 \mathrm{ft})$ area per cover type (after Yahner 1988). Cotton was used as bedding, and a small amount of peanut butter was put in each trap as bait just before dusk. Traps were checked on two consecutive mornings. Number of individuals trapped per species, date of capture, and location of capture relative to cover types were noted for each survey (Smith and Vrieze 1979; Yahner 1983). Sex and age (if known), reproductive condition, and individual identification (e.g., ear tag or toe clip) were recorded (Rose and Dueser 1980).

Because vegetative was sparse in the grass cover type each year, traps in this type were not set until August. Also, in September 2006, trapping was not conducted because of heavy rains caused by hurricane conditions. Small mammals were sampled a total of 342 trap nights (TN) in 2005 and 276 $\mathrm{TN}$ in 2006.

\section{RESULTS AND DISCUSSION}

Thirty-one small mammals (27 white-footed mice, Peromyscus leucopus; three northern short-tailed shrews, Blarina brevicauda; one meadow vole, Microtus pennsylvanicus) were noted in 2005 and 2006. This included 19 in 2005 and 12 in 2006, which attests to the value of conducting a study on fauna for more than 1 year. The number of individuals noted at the Green Lane ROW and adjacent forest was much lower than 121 individuals (eight species) trapped at the SGL 33 area in 2004 and 2005. The capture rate was 5.2 individuals/100 TN in both years combined in the current study. This 
was considerably lower than 27.0 individuals/100 TN noted in 1989 through 1990 or 10.3 animals captured/100 TN in 2004 through 2005 at the SGL 33 area (Bramble et al. 1992; Yahner et al. 2007).

Most individuals $(n=13)$ of all species combined were in the shrub cover type, which represented a well-vegetated border zone created by integrated vegetation management (Bramble et al. 1985; Yahner and Hutnik 2004). The relative lack of mammals at the Green Lane area is not surprising based on other studies (e.g., Beer 1961; Yahner et al. 2007). As plant succession progresses, meadow voles would be expected in the grass cover type because it is a grassland specialist (Grant 1971).

In spring, abundance of small mammals was low at the Green Lane area (after Yahner 1983; Merritt 1987; Yahner et al. 2007). As the year progressed, reproduction and food resources increased, thereby resulting in more mammals captured. Reproductive adults occurred in May, and juvenile white-footed mice were captured in August.

We have no explanation for lowered diversity and abundance of small mammals at the Green Lane area compared with the SGL 33 area, except that land uses proximal to each ROW were dramatically different. For instance, land uses surrounding the Green Lane area were early successional areas, not unlike that found on the Green Lane ROW. In contrast, land use proximal to the ROW at the SGL 33 area was contiguous forest (Yahner et al. 2007), and the ROW represented an early successional habitat amid a forested landscape.

Herbicides were used for vegetation maintenance on the ROW at both areas (Yahner 2006). These chemicals had no long-term impact on other fauna or their food resources (Bramble et al. 1999; Yahner et al. 2003).

Acknowledgments. Cooperation was provided by Asplundh Tree Expert Co., Commonwealth Edison, Dow AgroSciences, and Philadelphia Electric Company.

\section{LITERATURE CITED}

Beer, J.R. 1961. Winter home ranges of the red-backed mouse and the deer mouse. Journal of Mammalogy 42: 174-180.

Bramble, W.C., W.R. Byrnes, and R.J. Hutnik. 1985. Effects of a special technique for right-of-way maintenance on deer habitat. Journal of Arboriculture 11:278-284.

Bramble, W.C., R.H. Yahner, and W.R. Byrnes. 1999. Effect of herbicide maintenance of an electric transmission line right-of-way on butterfly populations. Journal of Arboriculture 25:302-310.
Bramble, W.C., R.H. Yahner, W.R. Byrnes, and S.A. Liscinsky. 1992. Small mammals in plant cover types on an electric transmission right-of-way. Journal of Arboriculture 18:316-321.

Grant, P.R. 1971. The habitat preference of Microtus pennsylvanicus and its relevance to the distribution of this species on an island. Journal of Mammalogy 52:351-356.

Merritt, J.D. 1987. Guide to the Mammals of Pennsylvania. University of Pittsburgh Press, Pittsburgh, PA. 408 pp.

Rose, R.K., and R.D. Dueser. 1980. Lifespan of Virginia meadow voles. Journal of Mammalogy 61:760-763.

Smith, A.T., and J.M. Vrieze. 1979. Population structure of Everglade rodents: Responses to a patchy environment. Journal of Mammalogy 60:778-794.

Yahner, R.H. 1983. Small mammals in farmstead shelterbelts: Habitat correlates of seasonal abundance and community structure. The Journal of Wildlife Management 47:74-84.

- 1988. Small mammals associated with even-aged aspen and mixed-oak forest stands in central Pennsylvania. Journal of the Pennsylvania Academy of Science 62: $122-126$.

- 2006. Wildlife habitat, herbicides, and rights-of-way maintenance-integrated vegetation management and the wire-border zone method. Natural Areas Journal 26: 114-115.

Yahner, R.H., and R.J. Hutnik. 2004. Integrated vegetation management on an electric transmission right-of-way in Pennsylvania, U.S. Journal of Arboriculture 30:295-300.

. 2005. A 15-year follow-up to vegetation on an electric transmission right-of-way in southeastern Pennsylvania. Journal of the Pennsylvania Academy of Science 79: 72-74.

Yahner, R.H., R.J. Hutnik, and S.A. Liscinsky. 2003. Longterm trends in bird populations on an electric transmission right-of-way. Journal of Arboriculture 29:156-164.

Yahner, R.H., R.T. Yahner, and R.J. Hutnik. 2007. Longterm trends in small mammals on a right-of-way in Pennsylvania. Arboriculture and Urban Forestry. 33:147-152.

Richard H. Yahner (corresponding author)

School of Forest Resources

College of Agricultural Sciences

The Pennsylvania State University

University Park, PA 16802, U.S.

rhy@psu.edu

Richard T. Yahner

202 Amblewood Way

State College, PA 16803, U.S. 